\title{
Erratum to: The prevalence of recognized contributors to secondary osteoporosis in South East Asian men and post-menopausal women. Are $Z$ score diagnostic thresholds useful predictors of their presence?
}

\author{
Chee Kwang Yung • Stephanie Fook-Chong • \\ Manju Chandran
}

Published online: 16 October 2012

(C) International Osteoporosis Foundation and National Osteoporosis Foundation 2012

\section{Erratum to: Arch Osteoporos}

$$
\text { 10.1007/s11657-012-0078-z }
$$

Unfortunately the article was published with an error in Table 2 (Prevalence of common conditions known to cause secondary osteoporosis). The total prevalence of common conditions as well as the seperate prevalence of the various conditions in males and females was inadvertently reversed. The authors sincerely apologize for the mistake and are pleased to take this opportunity to publish a corrected version of the table.
Table 2 Prevalence of common conditions known to cause secondary osteoporosis

\begin{tabular}{lccc}
\hline & \multicolumn{2}{c}{ Prevalence by gender } & $\begin{array}{l}\text { Overall } \\
\text { prevalence } \\
\text { nynn }\end{array}$ \\
\cline { 2 - 3 } & Male (\%) & Female (\%) & \\
\hline $\begin{array}{l}\text { Prevalence of secondary } \\
\text { osteoporosis due to } \\
\text { commonly identified }\end{array}$ & 62.5 & 44.4 & 47.6 \\
$\quad$ causes & 34 & 18.8 & \\
$\begin{array}{l}\text { Hypercalciuria } \\
\text { Vitamin D deficiency }\end{array}$ & 25.5 & 17 & 21.63 \\
$\begin{array}{l}\text { Hyperthyroidism } \\
\text { Glucocorticoid use }\end{array}$ & 19.5 & 8.5 & 18.5 \\
$\begin{array}{l}\text { Hyperparathyroidism } \\
\text { Primary }\end{array}$ & 12.5 & 7.8 & 8.43 \\
$\begin{array}{l}\text { Secondary } \\
\text { Male hypogonadism }\end{array}$ & 2.2 & 1.2 & 1 \\
\hline
\end{tabular}

The online version of the original article can be found at http:// dx.doi.org/10.1007/s11657-012-0078-z.

C. K. Yung $\cdot$ M. Chandran $(\bowtie)$

Department of Endocrinology, Osteoporosis and Bone Metabolism

Unit, Singapore General Hospital,

Outram Road,

Singapore 169608, Singapore

e-mail: manju.chandran@sgh.com.sg

\section{S. Fook-Chong}

Department of Biostatistics and Clinical Research,

Singapore General Hospital,

Outram Road,

Singapore 169608, Singapore 